pear in periodicals and in book form. His Life Histories of Manitoba Mammals was published by him as Naturalist for the Province. The writings were well received and he was able to purchase a nice estate near Greenwich, Conn., U.S.A. where he set up his collections of sketches, paintings, skins and photographs. From here he ranged over the continent, his travels including a long trip to Aylmer Lake north of the Peace River country. $\mathrm{He}$ also made another visit to Saskatchewan with respect to the conservation of the antelope and of wild life in general.

As a raconteur he was unexcelled and his lectures were always well attended. Perhaps one remembered most the personal enecdotes which he used to illustrate some natural la that he had learned or some gem information which he had collects in his travels.

Some of his contemporaries et deavoured to say that he was mere a writer of nursery stories but t\} publication of his Life Histories enced his critics and brought hi great acclaim.

Seton always called himself artist naturalist. As an artist received his training in England ar France, as a naturalist his bas training in Canada. He never fail to mention how kind the west $h$ been to him in material.

He died at Seton Village ne Santa $\mathrm{Fe}$, on the last ramparts of $t$ Rockies where the Buffalo wind w always blowing.

\title{
An Interesting and Beautiful Native Plant
}

\author{
By W. C. McCALLA, Calgary
}

On August 10th 1923 I was botanizing in the Lethbridge area, and in tramping up and down the steep slopes I saw a plant new to me. The large white flcwer buds, 2 inches long, caught the eye first, then, in strong contrast, the harsh foilage very rough to the touch and clinging to one's clothes quite readily. Several times during the day I came across this same species but saw no open flowers.

After an early dinner I went back and saw to my delight that the splended flowers were beginning to open showing the numerous yellow stamens. As I watched, the flowers continued to expand until some of them were $33 / 4$ inches across. The light was failing and I wanted a close-up photograph of the flowers, one that would record in proper tone the yellow stamens, and in those days that meant using a filter thus lengthening the exposure-and the wind was blowing!

I selected and cut off a good flowering stem, put it into my collecting case and hurried to my hotel room. The flowers came out of the case in perfect condition. I placed the stem near the window with a grey card as a background, consulted the light meter, and gave an expos of $2 \frac{1}{2}$ minutes, F16, Isos 2 filt Com. Ortho film. Such a long ex sure might make the eyebrows some of my readers go up now $t$ fast panchromatic film and fl bulbs are common place. The companying illustration is reprodu from the photograph taken evening.

I am writing of course of $M e$ zelia decapetala (Pursh) Urban Gilg. Of its common names Even Star is most appropiate as the flow open only in the evening. From limited experience I cannot exact times but they seem to stari open about 6 p.m. and to close at p.m. or earlier.

As I have found them the pe are almost white with only a $f$ suggestion of cream colour. In $S$ of careful handling mine tur brown in the press.

A good description of this $p$ is given in A. C. Budd's Flora of Canadian Prairies.

Gray's Manual, 8th edition, g its range as "N. W. Ia. to Sask. Alta., to Okla., Tex. and Nev." Canada it is found across the sor ern part of the prairies but it is common. 


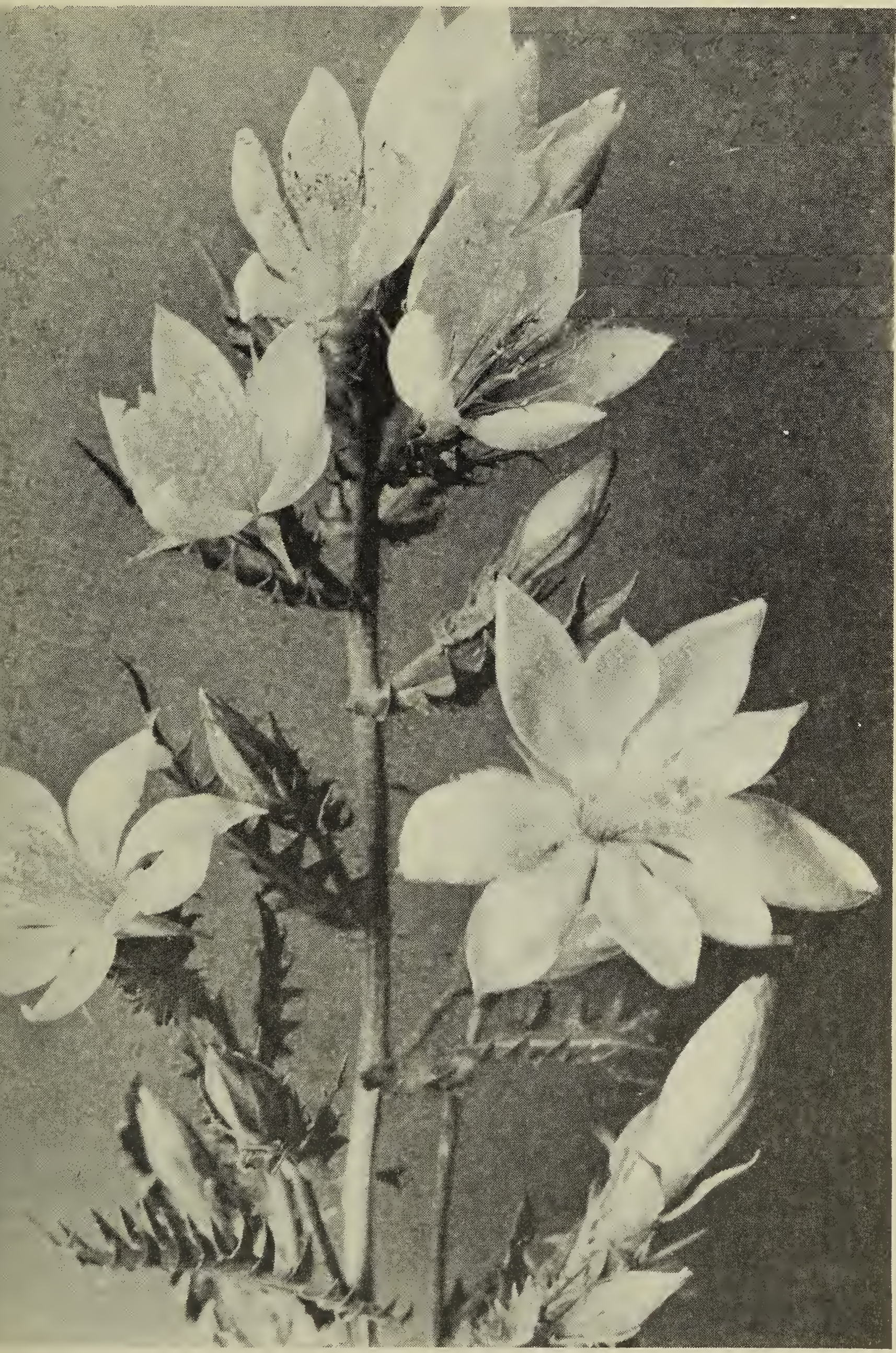

Photo by W. C. McCalla

\section{EVENING STAR}

Mentzelia decapetala (Pursh) Urban and Gilg ( $3 / 5$ nat. size) 